\title{
Modifications in the methods to extract pectin from cv. "Pedro Sato" guavas during ripening
}

\author{
Modificações nos métodos de extração de pectina em goiabas cv. "Pedro Sato" \\ durante amadurecimento
}

\section{Samira Haddad Spiller ${ }^{1 \star}$, Tamara Rezende Marques ${ }^{1}$, Anderson Assaid Simão', Mariana Aparecida Braga', Lucimara Nazaré Silva Botelho', Gustavo Henrique Andrade Machado', Rodrigo Martins Fráguas², Custódio Donizete dos Santos ${ }^{1}$}

\author{
${ }^{1}$ Universidade Federal de Lavras (UFLA), Departamento de Química, Lavras/MG - Brasil \\ 2 Faculdade Marechal Rondon (FARON), Departamento de Química, Villhena/RO - Brasil
}

\section{*Corresponding Author}

Samira Haddad Spiller, Universidade Federal de Lavras (UFLA), Departamento de Química, Campus Universitário, Caixa Postal: 3037, CEP: 37200-000, Lavras/MG - Brasil, e-mail: samirahspiller@yahoo.com.br

Cite as: Modifications in the methods to extract pectin from cv. "Pedro Sato" guavas during ripening. Braz. J. Food Technol., v. 21, e2017032, 2018.

\section{Abstract}

Guava is a highly perishable fruit due to its intense metabolism during ripening, with a shelf life of up to five days at room temperature. The loss of firmness during ripening is caused by the activity of hydrolytic enzymes that promote dissolution of the pectin constituents of the cell wall. Although guava is considered to be rich in pectin, the amounts reported in the literature do not exceed $2.4 \%$, a content indicating it is not responsible for the firmness of guava. The aim of this study was to extract pectin from the guava pulp during 7 days of ripening by two methods (ethanol and EDTA extraction) and suggest modifications in the methods by adding to the extraction residue, cellulase and pectinase to degrade the cell wall structure of the fruit and obtain larger amounts of pectin, which would imply the participation of pectin in the maintenance of fruit firmness. It was possible to infer there were no differences in the pectin levels extracted by the two methods, due to sugar contamination. As from the new stage in the execution by the two methods, the extraction was more efficient: $9.10 \%$ of pectin with EDTA and $7.63 \%$ with ethanol. The pectin contents found were higher than those mentioned in the literature, better explaining their responsibility in fruit firmness.

Keywords: Firmness; Hydrolytic enzymes; Storage; Room temperature.

\section{Resumo}

A goiaba é uma fruta altamente perecível, devido ao seu intenso metabolismo durante o amadurecimento, com vida útil que pode chegar a cinco dias em temperatura ambiente. A perda de firmeza durante o amadurecimento é devida à atividade das enzimas hidrolíticas, que promovem a solubilização dos constituintes da pectina da parede celular. Embora a goiaba seja considerada rica em pectina, as quantidades relatadas na literatura não excedem $2,4 \%$ e tal conteúdo não explica a sua responsabilidade pela firmeza dos frutos. O objetivo deste estudo foi extrair pectina da polpa de goiaba durante sete dias de amadurecimento, por dois métodos (extração de etanol e EDTA). Sugerem-se modificações nos métodos, adicionando aos resíduos de extração, celulase e pectinase para degradar a estrutura da parede celular do fruto e obter maiores quantidades de pectina e, portanto, implicar sua participação na manutenção da firmeza dos frutos. Foi possível inferir que não há diferenças nos níveis de pectina extraídos pelos dois métodos, devido à contaminação do açúcar. A partir da nova etapa de execução nos métodos, a extração foi mais eficiente: 9,10\% de pectina com EDTA e 7,63\% com etanol. Os conteúdos de pectina encontrados foram superiores aos mencionados na literatura, explicando melhor sua responsabilidade na firmeza dos frutos.

Palavras-chave: Firmeza; Enzimas hidrolíticas; Armazenamento; Temperatura ambiente. 


\section{Introduction}

Brazil is a country with an extensive land area but only $5 \%$ of this area is used for the culture of fruit. Nevertheless the culture of fruit is an activity of extreme importance in Brazil due to several factors: employment generation, better regional income distribution, generation of products with commercial value, and expectations for the internal and external markets. Guava stands out amongst the Brazilian fruits (Psidium guajava L.), and Brazil is the largest producer of red guavas. Exports are destined for the European market with no postharvest treatment (VIEIRA et al., 2014).

Guava is a tropical climate fruit that has shown a great increase in planted areas, with the largest share of the fruits produced being destined for industrialization, although there has also been significant growth in the fresh guava market, especially in large urban centers, highlighting the cv. "Pedro Sato", due to its extensive production, nutritional value, acceptance (due to its pleasant taste), attractive colour and a high vitamin $\mathrm{C}$ content (SOUZA; AMATO NETO, 2009; OLIVEIRA et al., 2012). Guava is one of the main raw materials used by the canning industry in Brazil, allowing for various forms of exploitation, for example, puree, pulp, nectar, juice, jam, ice cream and candy (ABREU et al., 2012b).

Highly perishable due to its intense metabolic activity during ripening, the guava has a lifetime that can reach 3 to 5 days at room temperature, after which the decrease in firmness is the most striking feature of the maturation process (ABREU et al., 2012b). Softening (related to maturation) of the fruit is generally associated with chemical modifications and degradation of the cell wall components as well as a decrease in fruit integrity, such as the pectin content, during ripening (VILAS BOAS et al., 2013).

Pectin polymers are considered primarily responsible for the firmness of green fruits (ABREU et al., 2012a), and their degradation is one of the most notable events during ripening and softening of the fruit, and this is also the case with guavas. However, the pectin content reported in the literature for guava pulp (about 2.5\% fresh weight and $15 \%$ dry weight) (XISTO et al., 2004; LINHARES et al., 2007) is very low to be considered the main component responsible for the maintenance of firmness. According to Abreu et al. (2012a), throughout the ripening of guava $\mathrm{cv}$. Pedro Sato, the pectin from the cell wall gradually migrates into the cell, probably into the vacuoles, and the function of this migration is still unexplained.

The loss of firmness during ripening of the fruits can also be explained as being due to the activity of hydrolytic enzymes that promote intense dissolution of the pectins present in the cell wall, the main activities being those of pectinmethylesterase and polygalacturonase (JAIN et al., 2001; OLIVEIRA et al., 2006). However the guava cv. Pedro Sato does not present polygalacturonase activity (LINHARES et al., 2007) or it is very low and decreases with ripening (XISTO et al., 2004) and hence the rapid decrease in firmness still remains unexplained.

Thus the objective of the present study was to extract pectin from guava pulp during 7 days ripening at room temperature by two methods (extraction with 95\% ethanol and EDTA), and suggest modifications in the methods in order to obtain larger amounts of pectin from the guava pulp, which could imply in a greater involvement of these molecules in the maintenance of fruit firmness.

\section{Material and methods}

\subsection{Fruit origin and harvest}

Guavas (Psidium guajava L.) cv. "Pedro Sato" were harvested from an orchard located in Lavras, Minas Gerais, Brazil, altitude $845 \mathrm{~m}$, latitude $21^{\circ} 15^{\prime} \mathrm{S}$, and longitude $45^{\circ} 22^{\prime} \mathrm{W}$, in January 2013 . They were harvested by hand in the early morning, at the stage of maturity in which the fruits were still green. They were packed into polystyrene boxes and transported to the Laboratory in order to carry out the analyses.

\subsection{Preparation of the fruits}

For the tests, the harvested fruits were selected based on their size, colour and the absence of physiological and mechanical injuries, washed in tap water and separated into 8 groups of 9 fruits each for the treatments. All the fruits were immersed in a $1 \%$ solution of sodium hypochlorite at $20^{\circ} \mathrm{C}$ for 5 minutes for disinfection. They were numbered and stored on a shelf in the laboratory and kept for 7 days at room temperature $\left(22{ }^{\circ} \mathrm{C} \pm 1{ }^{\circ} \mathrm{C}\right)$ and $78 \% \pm 1 \% \mathrm{RH}$.

\subsection{Sample preparation}

Samples were prepared on the day of harvest and then every day up to the end of the ripening period. The endocarp was removed and the fruit pulp chopped into pieces of approximately $1 \mathrm{~cm}^{3}$ and packed into three plastic bags with three fruits in each bag, and frozen for subsequent analysis.

\subsection{Experimental design}

The experimental design was completely randomized, with 8 treatments $(0,1,2,3,4,5,6$ and 7 days of ripening) and 3 replications ( 3 fruits) per treatment. The results were subjected to an analysis of variance using the statistical program R (R CORE TEAM, 2012). The treatment means were compared using regression. 


\section{Analyses}

\subsection{Mass loss}

Mass loss was determined from the difference between the initial mass and the mass of the fruits on each day of storage.

\subsection{Pectin extraction}

The soluble and insoluble fractions, as well as the residue (fraction resulting after the determination of insoluble pectin) were analysed, using two extraction methods; the first using 95\% ethanol (McCREADY; McCOOMB, 1952), and the second using a $2.0 \mathrm{mM}$ tetrasodium EDTA $2.0 \mathrm{mM}$ solution, pH 7.0 (ABREU et al., 2012b). The extracts were quantified colorimetrically by way of the reaction with carbazole using the technique of Bitter and Muir (1962). The levels were expressed as $g$ of galacturonic acid per $100 \mathrm{~g}$ of pulp.

\section{a) First method using 95\% ethanol}

The methodology was that proposed by McCready and McCoomb (1952) for insoluble pectin: $1.0 \mathrm{~g}$ of sample was weighed $(1.0 \mathrm{~g}$ of pure guava was previously macerated with the aid of a mortar and pestle, without the addition of solvents) and $10.0 \mathrm{~mL}$ of $95 \%$ ethyl alcohol added and left to rest overnight. The samples were then subjected to agitation (mechanical shaker at $60 \mathrm{rpm}$ and $25^{\circ} \mathrm{C}$ ) for 1 hour, filtered through filter paper, and washed with two $4.0 \mathrm{~mL}$ portions of $95 \%$ ethyl alcohol. The filtrate was stored. An aliquot of $10.0 \mathrm{~mL}$ of $11.06 \mathrm{mM}$ EDTA, $\mathrm{pH}$ 11.0, was then added to the residue on the filter paper, and after 30 minutes, the $\mathrm{pH}$ was adjusted to 5.0 with $10 \%$ acetic acid and $50 \mathrm{mg}$ of pectinase (Sigma Aldrich, $1.02 \mathrm{U} . \mathrm{mg}^{-1}$ ) added. After 1 hour of agitation (mechanical stirrer at $60 \mathrm{rpm}$ and $25^{\circ} \mathrm{C}$ ), the mixture was filtered and $20.0 \mathrm{~mL}$ of the EDTA solution added to the supernatant. Thus the total pectin was obtained and quantified, and the value obtained for soluble pectin subtracted to obtain the insoluble pectin.

To obtain the soluble fraction according to the same methodology, $10.0 \mathrm{~mL}$ of distilled water, instead of the EDTA solution, were added to the residue on the filter paper, and after one hour of agitation, the mixture was filtered and the supernatant stored.

\section{b) Second method using a tetrasodium EDTA solution}

This was carried out according to the methodology proposed by Abreu et al. (2012b), with modifications: $0.25 \mathrm{~g}$ of sample $(0.25 \mathrm{~g}$ pure guava was macerated in advance, without the addition of solvents, with the aid of a mortar and pestle) was weighed and $10.0 \mathrm{~mL}$ of a $2.0 \mathrm{mM}$ EDTA solution, pH 7. 0 added. The sample was then placed in boiling water for 5 minutes and centrifuged at $5.000 \times \mathrm{g}$ at $25^{\circ} \mathrm{C}$ for 5 minutes. This supernatant was designated as SOB 1 and the sediment as SED 01.

$40.0 \mathrm{~mL}$ of cold absolute ethanol were added to the supernatant and placed in the freezer, and after 1 hour centrifuged at $5.000 \times \mathrm{g}$ at $4{ }^{\circ} \mathrm{C}$ for 5 minutes. An aliquot of $2.5 \mathrm{~mL}$ of distilled water was added to the sediment and the weight of soluble pectin obtained.

An aliquot of $20.0 \mathrm{~mL}$ of $2.0 \mathrm{mM}$ EDTA, pH 7.0, was added to the sediment (SED 01) and the $\mathrm{pH}$ subsequently adjusted to 5.0 with $10 \%$ acetic acid. $50 \mathrm{mg}$ of pectinase (Sigma Aldrich, $1.02 \mathrm{U} . \mathrm{mg}^{-1}$ ) were then added and after 1 hour of agitation (mechanical stirrer at $60 \mathrm{rpm}$ at $25^{\circ} \mathrm{C}$ ), the sample was centrifuged at $5.000 \times \mathrm{g}$ at $25^{\circ} \mathrm{C}$ for 5 minutes. The supernatant (insoluble pectin) was stored. A $5.0 \mathrm{~mL}$ aliquot of a $2.0 \mathrm{mM}$ EDTA solution, $\mathrm{pH}$ 7.0, was added to the sediment (SED 02), and the $\mathrm{pH}$ adjusted to 5.0 with $10 \%$ acetic acid. After adding $50 \mathrm{mg}$ of cellulase (Sigma Aldrich, 0.8 U. $\mathrm{mg}^{-1}$ ), the sample was placed in a water bath at $30{ }^{\circ} \mathrm{C}$ overnight. The next day the sample was centrifuged at $5.000 \times \mathrm{g}$ at $25^{\circ} \mathrm{C}$ for 5 minutes, the supernatant discarded, $5.0 \mathrm{~mL}$ of $2.0 \mathrm{mM}$ EDTA solution, $\mathrm{pH} 7.0$, added to the sediment, and the $\mathrm{pH}$ adjusted to 5.0 with $10 \%$ acetic acid. After adding $50 \mathrm{mg}$ of pectinase, the sample was agitated for 1 hour and then centrifuged at $5.000 \times \mathrm{g}$ at $25^{\circ} \mathrm{C}$ for 5 minutes. The supernatant was stored and designated as the pectin residue (PR), and the sediment was discarded.

\subsection{Determination of sugars}

The sugars present in each fraction were determined by the anthrone method (DISCHE, 1962). The results were expressed as percentages ( $\mathrm{g} 100 \mathrm{~g}^{-1}$ fresh pulp).

\subsection{Interference of sugars in the pectin analysis}

With the aim of assessing the interference of sugars on the analysis of pectin using carbazole (BITTER; MUIR, 1962) and also the influence of pectin on the analysis of sugars using anthrone (DISCHE, 1962), several standard curves were constructed in the presence of various glucose concentrations for each pectin concentration. The pectin concentrations used were: $0,10,20,30,40$ and $45 \mu \mathrm{g} \mathrm{mL}^{-1}$ and the glucose concentrations were: $0,5,10,15,20$ and $25 \mathrm{\mu g} \mathrm{mL}^{-1}$. Response surface-type graphs were constructed for each analysis.

\section{Results and discussion}

\subsection{Mass loss of the fruit}

The weight loss at the end of the storage period was $15.4 \%$ (Figure 1). According to Chitarra and Chitarra (2005), a mass loss of up to $15 \%$ does not affect the appearance of the fruit. The weight loss of fruits is an important variable that is directly related to the quality of the fruit and is a major problem during storage due to 
the sweating process. The loss of water leads to tissue softening, making the fruits more susceptible to damage and changes in colour and flavour (AZZOLINI et al., 2004). The acceptable values for the weight loss of different cultivars range between $10.0 \%$ and $15.0 \%$ (XISTO et al., 2004), and thus it can be stated that the results of this study were within this range, with a very small variation.

The mass loss of stored guavas varied for each researcher according to the experimental conditions used. Linhares et al. (2007), when analysing the loss of mass of "Pedro Sato" guavas treated with calcium chloride and 1-methylcyclopropene and stored under refrigeration, found mass losses of $21.13 \%$ and $18.60 \%$, respectively, at the end of 25 days of storage, while Xisto et al. (2004) observed a mass loss of $13.80 \%$ for "Pedro Sato" guavas treated for 4 days with calcium chloride and stored at room temperature. Although the percentage of mass loss verified in the present study was within the acceptable range for consumption by the end of 8 days of storage, the fruits showed yellowing and a less crunchy texture besides being softened, making their use impractical for the trading of fresh fruit.

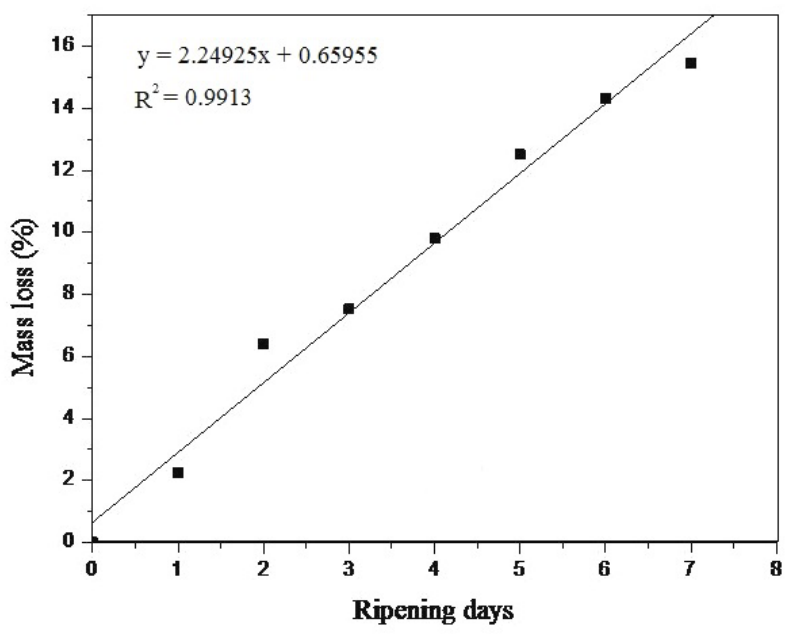

Figure 1. Percentage of mass loss of the "Pedro Sato" guavas stored during 7 days of ripening under ambient conditions.

\subsection{Pectin content}

Table 1 shows the results obtained for the analyses of pectin extraction using the methods proposed by McCready and McCoomb (1952) and by Abreu et al. (2012b) during the ripening of "Pedro Sato" guavas.

The results found for the soluble and insoluble pectins using the methodology proposed by McCready and McCoomb (1952) were in agreement with the results found in the literature: the soluble pectin increased and the insoluble pectin decreased during ripening. The sum of these two fractions (soluble and insoluble pectin - SP and IP), giving from $2.29 \%$ to $2.35 \%$ during the ripening of guavas, is consistent with the values found in the literature (Table 1).

When the extraction method described by Abreu et al. (2012b) was used, there was an increase in the contents of soluble and insoluble pectin, but the behaviour was similar to that shown using the method of McCready and McCoomb (1952), that is, the soluble pectin levels increased and the insoluble pectin levels decreases in an equivalent way during ripening. The sum of these two fractions (soluble and insoluble pectin - SP and IP) was $3.73 \%$ a $3.81 \%$ during the ripening of the guavas (Table 1). These values are slightly above those recorded in the literature.

The pectin polymers are considered to be the main component responsible for the firmness of green fruits (ABREU et al., 2012b) and their degradation by enzymes such as pectinmethylesterase (PME) and polygalacturonase (PG) during ripening causes softening and a loss of fruit firmness. Guava acts in the same way, but the amounts of pectin found in the guava pulp (around 2.5\% fresh weight and $15 \%$ dry weight) are too small to be considered the primary component responsible for the maintenance of firmness. Abreu et al. (2012b), by analysing the fractionation of the sugars and the chemical composition of "Pedro Sato" guavas, suggested that the amount of pectin in guavas should be greater than the $2.5 \%$ fresh weight (or $15 \%$ dry weight) reported in the literature.

Another factor to be considered is also the large variation in the amount of pectin found during ripening.

Table 1. Average contents (\%) of soluble pectin (SP) and insoluble pectin (IP) according to two extraction methods, in the "Pedro Sato" guavas during 7 days of ripening under ambient conditions $\left(22{ }^{\circ} \mathrm{C} \pm 1{ }^{\circ} \mathrm{C}\right.$ and $\left.78 \% \pm 1 \% \mathrm{RH}\right)$.

\begin{tabular}{cccccccccc} 
Day & $\mathbf{0}$ & $\mathbf{1}$ & $\mathbf{2}$ & $\mathbf{3}$ & $\mathbf{4}$ & $\mathbf{5}$ & $\mathbf{6}$ & $\mathbf{7}$ \\
$\mathrm{SP}^{*}$ & $0.10^{\mathrm{aA}}$ & $0.13^{\mathrm{bA}}$ & $0.16^{\mathrm{cA}}$ & $0.24^{\mathrm{dA}}$ & $0.29^{\mathrm{eA}}$ & $0.35^{\mathrm{fA}}$ & $0.39^{\mathrm{gA}}$ & $0.42^{\mathrm{hA}}$ \\
$\mathrm{SP}^{* *}$ & $0.23^{\mathrm{aB}}$ & $0.34^{\mathrm{bB}}$ & $0.40^{\mathrm{cB}}$ & $0.46^{\mathrm{dB}}$ & $0.56^{\mathrm{eB}}$ & $0.62^{\mathrm{fB}}$ & $0.68^{\mathrm{gB}}$ & $0.76^{\mathrm{hB}}$ \\
$\mathrm{IP}^{*}$ & $2.25^{\mathrm{aC}}$ & $2.20^{\mathrm{aC}}$ & $2.13^{\mathrm{bC}}$ & $2.09^{\mathrm{bC}}$ & $2.06^{\mathrm{cC}}$ & $1.98^{\mathrm{dC}}$ & $2.00^{\mathrm{dC}}$ & $1.93^{\mathrm{eC}}$ \\
$\mathrm{I}^{* *}$ & $3.50^{\mathrm{aD}}$ & $3.42^{\mathrm{aD}}$ & $3.39^{\mathrm{aD}}$ & $3.27^{\mathrm{bD}}$ & $3.20^{\mathrm{bD}}$ & $3.19^{\mathrm{bD}}$ & $3.09^{\mathrm{cD}}$ & $3.03^{\mathrm{cD}}$ \\
\hline
\end{tabular}

Means followed by the same lower letter in each column and capital letter in each line are not statistically different from each other at $5 \%$ significance level according to the Scott-Knott test; ${ }^{\star}$ Extraction with 95\% ethanol; ${ }^{\star *}$ Extraction with tetrasodium EDTA solution (2.0 mM; pH 7.0). 
The assertion that "the amount of total pectin can increase, decrease or remain constant" (CARVALHO et al., 2001; XISTO et al., 2004; LINHARES et al., 2007; MENDONÇA et al., 2007; VILA et al., 2007) reflects the uncertainty of the results when it comes to this substance (ABREU et al., 2012b).

Considering the repetition of the results found in the literature, a new step in the extraction of the pectin by the two methods tested, was proposed: after the determination of the insoluble pectin, the residue was treated with cellulase and pectinase in order to degrade the structure of the fruit cell wall and release other pectin molecules, which are hydrolysed by the pectinase, and designated here as the pectin residue (PR).

The results are shown in Table 2. Large amounts of pectin were trapped in the cell walls of the fruit using the two methods tested, since the amounts of pectin in the pectin residue (PR) were similar for both methods. There was no significant difference between the storage days or between the two methods.

The amounts of pectin in the PR fractions were the same (Table 2), concluding that the soluble and insoluble pectin fractions were completely extracted in both methods. If this hypothesis were true, the amounts of soluble (SP) and insoluble (IP) pectin were also expected to be the same by both methods, but the method proposed by Abreu et al. (2012b) resulted in higher levels of SP and IP (Table 1), suggesting the interference by sugar which is also extracted in this method.
To verify the total pectin content (TP) obtained from the new extraction step using the two methods, the sum of the soluble (SP), insoluble (IP) and residual (PR) pectins was obtained. The values found by the first extraction method (McCREADY; McCOOMB, 1952) were similar to those suggested by Abreu et al. (2012b), based on the fractionation of sugars and the chemical composition. However, the values for TP obtained using the second extraction method were higher due to higher amounts of soluble and insoluble pectins (Table 2).

To confirm the interference by sugars, the sugars were then analysed in the SP, IP and PR fractions (Table 3). The results showed higher values for sugars in the SP and IP fractions using the method described by Abreu et al. (2012b) and equal values for PR using both methods, confirming the interference of sugar in the soluble and insoluble pectin contents extracted by the method of Abreu et al. (2012b).

Response surface-type graphs were constructed with various galacturonic acid concentrations and various glucose concentrations, and the pectin concentration analysed with carbazole and with anthrone (Figure 2).

The results showed that there was no interference by pectin in the analysis of the sugars (Figure 2A), but significant interference by sugar in the analysis of pectin (Figure 2B). However, even with the interference by the sugars, the new step proposed in both methods revealed an increase in the total pectin content.

Table 2. Average pectin contents (\%) in the pectin residue (PR) and total pectin (TP) according to the two extraction methods in "Pedro Sato" guavas during 7 days of ripening under ambient conditions $\left(22^{\circ} \mathrm{C} \pm 1{ }^{\circ} \mathrm{C}\right.$ and $\left.78 \% \pm 1 \% \mathrm{RH}\right)$.

\begin{tabular}{cccccccccc} 
Day & $\mathbf{0}$ & $\mathbf{1}$ & $\mathbf{2}$ & $\mathbf{3}$ & $\mathbf{4}$ & $\mathbf{5}$ & $\mathbf{6}$ & $\mathbf{7}$ \\
$\mathrm{PR}^{\star}$ & $5.38^{\mathrm{aA}}$ & $5.43^{\mathrm{aA}}$ & $5.39^{\mathrm{aA}}$ & $5.42^{\mathrm{aA}}$ & $5.44^{\mathrm{aA}}$ & $5.43^{\mathrm{aA}}$ & $5.44^{\mathrm{aA}}$ & $5.39^{\mathrm{aA}}$ \\
$\mathrm{PR}^{\star *}$ & $5.40^{\mathrm{aA}}$ & $5.40^{\mathrm{aA}}$ & $5.37^{\mathrm{aA}}$ & $5.32^{\mathrm{aA}}$ & $5.39^{\mathrm{aA}}$ & $5.46^{\mathrm{aA}}$ & $5.41^{\mathrm{aA}}$ & $5.44^{\mathrm{aA}}$ \\
$\mathrm{TP}^{*}$ & $7.73^{\mathrm{aA}}$ & $7.75^{\mathrm{aA}}$ & $7.69^{\mathrm{aA}}$ & $7.76^{\mathrm{aA}}$ & $7.79^{\mathrm{aA}}$ & $7.76^{\mathrm{aA}}$ & $7.83^{\mathrm{aA}}$ & $7.73^{\mathrm{aA}}$ \\
$\mathrm{TP}^{* *}$ & $9.13^{\mathrm{aB}}$ & $9.17^{\mathrm{aB}}$ & $9.16^{\mathrm{aB}}$ & $9.05^{\mathrm{aB}}$ & $9.16^{\mathrm{aB}}$ & $9.27^{\mathrm{aB}}$ & $9.18^{\mathrm{aB}}$ & $9.24^{\mathrm{aB}}$ \\
\hline
\end{tabular}

Means followed by the same lower letter in each column and capital letter in each line are not statistically different from each other at $5 \%$ significance level according to the Scott-Knott test; * Extraction with 95\% ethanol; ** Extraction with tetrasodium EDTA solution (2.0 mM; pH 7.0).

Table 3. Total sugars (mg/100g) in the soluble (SP), insoluble (IP) and residual (PR) pectin fractions according to te two extraction methods, in the "Pedro Sato" guavas during 7 days ripening under ambient conditions $\left(22{ }^{\circ} \mathrm{C} \pm 1{ }^{\circ} \mathrm{C}\right.$ and $\left.78 \% \pm 1 \% \mathrm{RH}\right)$.

\begin{tabular}{ccccccccc}
\hline Day & $\mathbf{0}$ & $\mathbf{1}$ & $\mathbf{2}$ & $\mathbf{3}$ & $\mathbf{4}$ & $\mathbf{5}$ & $\mathbf{6}$ & $\mathbf{7}$ \\
$\mathrm{SP}^{*}$ & $0.26^{\mathrm{aA}}$ & $0.09^{\mathrm{aA}}$ & $0.13^{\mathrm{aA}}$ & $0.12^{\mathrm{aA}}$ & $0.34^{\mathrm{aA}}$ & $0.19^{\mathrm{aA}}$ & $0.10^{\mathrm{aA}}$ & $0.50^{\mathrm{aA}}$ \\
$\mathrm{SP}^{\star *}$ & $0.35^{\mathrm{aB}}$ & $0.70^{\mathrm{aB}}$ & $0.34^{\mathrm{aB}}$ & $0.25^{\mathrm{aB}}$ & $1.44^{\mathrm{aB}}$ & $1.48^{\mathrm{aB}}$ & $1.60^{\mathrm{aB}}$ & $1.17^{\mathrm{aB}}$ \\
$\mathrm{I}^{*}$ & $4.41^{\mathrm{aC}}$ & $3.84^{\mathrm{aC}}$ & $4.50^{\mathrm{aC}}$ & $4.36^{\mathrm{aC}}$ & $3.54^{\mathrm{aC}}$ & $4.11^{\mathrm{aC}}$ & $4.30^{\mathrm{aC}}$ & $4.74^{\mathrm{aC}}$ \\
$\mathrm{IP}^{* *}$ & $12.40^{\mathrm{aD}}$ & $10.19^{\mathrm{aD}}$ & $12.90^{\mathrm{aD}}$ & $10.08^{\mathrm{aD}}$ & $10.06^{\mathrm{aD}}$ & $13.13^{\mathrm{aD}}$ & $10.45^{\mathrm{aD}}$ & $11.85^{\mathrm{aD}}$ \\
$\mathrm{PR}^{*}$ & $.17 .97^{\mathrm{aE}}$ & $15.65^{\mathrm{aE}}$ & $15.55^{\mathrm{aE}}$ & $15.86^{\mathrm{aE}}$ & $16.49^{\mathrm{aE}}$ & $16.50^{\mathrm{aE}}$ & $16.96^{\mathrm{aE}}$ & $16.19^{\mathrm{aE}}$ \\
$\mathrm{PR}^{* *}$ & $17.77^{\mathrm{aE}}$ & $16.19^{\mathrm{aE}}$ & $16.86^{\mathrm{aE}}$ & $16.53^{\mathrm{aE}}$ & $16.25^{\mathrm{aE}}$ & $18.47^{\mathrm{aE}}$ & $16.94^{\mathrm{aE}}$ & $17.00^{\mathrm{aE}}$ \\
\hline
\end{tabular}

Means followed by the same lower letter in each column and capital letter in each line are not statistically different from each other at $5 \%$ significance level according to the Scott-Knott test; " Extraction with 95\% ethanol; **Extraction with tetrasodium EDTA solution (2.0 mM; pH 7.0). 

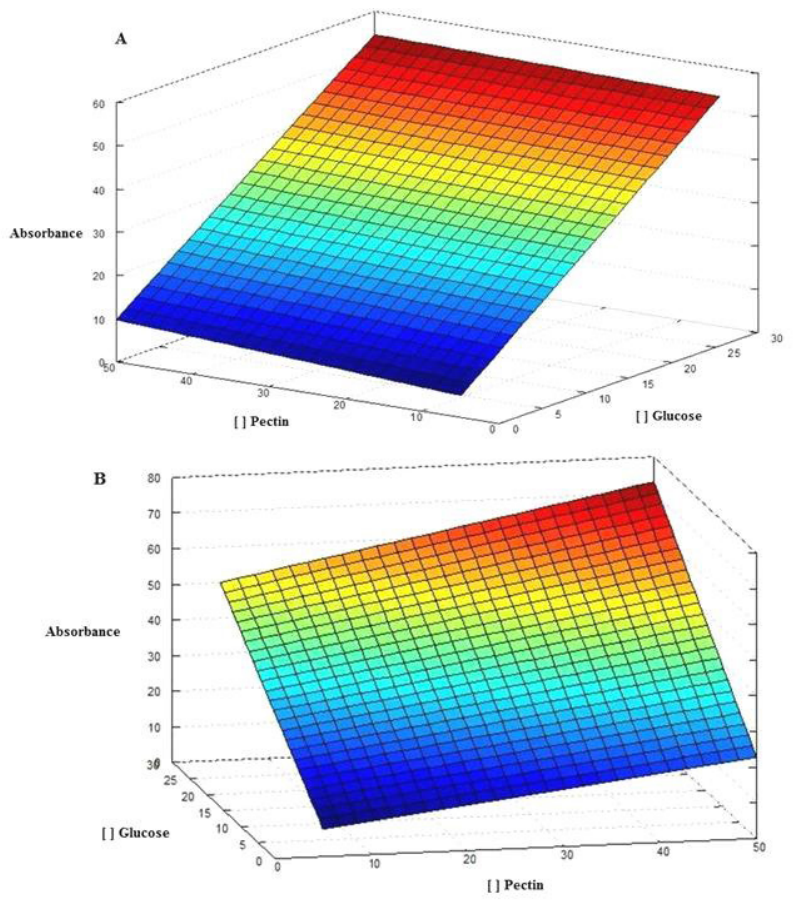

Figure 2. Response surfaces for the interference by pectin in the analysis of the sugar content $(A)$ and for the interference by sugar in the analysis of the pectin content (B).

\section{Conclusions}

From the comparison between the two methods evaluated, it was possible to infer there were no differences in the pectin levels extracted due to sugar contamination. However, when the new step proposed was included in the two extraction methods, it showed an increase in the pectin content in comparison to that reported in the literature. Thus with these more adequate contents, the pectin content can be implicated as responsible for the maintenance of fruit firmness.

\section{Acknowledgements}

The authors are grateful to the Fundação de Amparo à Pesquisa do Estado de Minas Gerais (FAPEMIG), Coordenação de Aperfeiçoamento de Pessoal de Nivel Superior (CAPES) and to the Conselho Nacional de Desenvolvimento Científico e Tecnológico (CNPq) for their financial support.

\section{References}

ABREU, J. R.; SANTOS, C. D.; ABREU, C. M. P.; CASTRO, E. M. Histochemistry and morphoanatomy study on guava fruit during ripening. Food Science and Technology, v. 32, n. 1, p. 179-186, 2012a. http://dx.doi.org/10.1590/S0101-20612012005000019.

ABREU, J. R.; SANTOS, C. D.; ABREU, C. M. P.; CORRÊA, A. D.; LIMA, L. C. O. Sugar fractionation and pectin content during the ripening of guava $\mathrm{cv}$. Pedro Sato. Revista Ciência e Tecnologia de Alimentos, v. 32, n. 1, p. 156-162, 2012b. http://dx.doi. org/10.1590/S0101-20612012005000029.

AZZOLINI, M.; JACOMINO, A. P.; SPOTO, M. H. F. Estádios de maturação e qualidade pós-colheita de goiabas 'Pedro Sato'. Revista Brasileira de Fruticultura, v. 26, n. 1, p. 29-31, 2004. http://dx.doi.org/10.1590/S0100-29452004000100009.

BITTER, T.; MUIR, H. M. A modified uronic acid carbazole reaction. Analytical Biochemistry, v. 4, n. 4, p. 330-334, 1962. PMid:13971270. http://dx.doi.org/10.1016/0003-2697(62)90095-7.

CARVALHO, H. A.; CHITARRA, M. I. F.; CHITARRA, A. B.; MENEZES, J. B. Eficiência da concentração de cloreto de cálcio e do tempo de imersão no tratamento pós-colheita de goiaba branca cv. Kumagai. Revista Brasileira de Fruticultura, v. 20, n. 3, p. 375-381, 2001.

CHITARRA, M. I. F.; CHITARRA, A. B. Pós-colheita de frutas e hortaliças: fisiologia e manejo. 2nd ed. Lavras: UFLA, 2005.

DISCHE, Z. General color reactions. In: WHISTLER, R. L.; WOLFRAM, M. L. (Ed.). Carbohydrate chemistry. New York: Academic, 1962. p. 477-512.

JAIN, N.; DHAWAN, K.; MALHOTRA, S. P.; SIDDIQUI, S.; SINGH, R. Compositional and enzymatic changes in guava (Psidium guajava L.) fruits during ripening. Acta Physiologiae Plantarum, v. 23, n. 3, p. 357-362, 2001. http://dx.doi.org/10.1007/s11738001-0044-7.

LINHARES, L. A.; SANTOS, C. D.; ABREU, C. M. P.; CORRÊA, A. D. Transformações químicas, físicas e enzimáticas de goiabas "Pedro Sato" tratadas na pós-colheita com cloreto de cálcio e 1-metilciclopropeno e armazenadas sob refrigeração. Ciência e Agrotecnologia, v. 31, n. 3, p. 829-841, 2007. http://dx.doi. org/10.1590/S1413-70542007000300033.

MCCREADY, R. M.; MCCOOMB, E. A. Extraction and determination of total pectic materials in fruits. Analytical Biochemistry, $v$. 42, n. 12, p. 1586-1588, 1952.

MENDONÇA, R. D.; FERREIRA, K. S.; SOUZA, L. M.; MARINHO, C. S.; TEIXEIRA, S. L. Características físicas e químicas de goiabas 'cortibel 1' e 'cortibel 4' armazenadas em condições ambientais. Bragantia, v. 66, n. 4, p. 685-692, 2007. http://dx. doi. org/10.1590/S0006-87052007000400019.

OLIVEIRA, A. C. G.; ZANÃO, C. F. P.; ANICETO, A. P. P.; SPOTO, M. H. F.; BRAZACA, S. G. C.; WALDER, J. M. M. Conservação pós-colheita de goiaba branca kumagai por irradiação gama: aspectos físicos, químicos e sensoriais. Boletim CEPPA, v. 24, n. 2, p. 375-396, 2006.

OLIVEIRA, I. P.; OLIVEIRA, L. C.; MOURA, C. S. F. T.; LIMA JÚNIOR, A. F.; ROSA, S. R. A. Guava cropping: from planting to plant management. Revista Faculdade Montes Belos, v. 5, n. 4, p. 137-156, 2012. 
Modifications in the methods to extract pectin from cv. "Pedro Sato" guavas during ripening

Spiller, S. H. et al.

R CORE TEAM. R: a language and environment for statistical computing. Vienna: R Foundation for Statistical Computing, 2012.

SOUZA, R. C.; AMATO NETO, A. J. As transações entre supermercados europeus e produtores brasileiros de frutas frescas. Gestão \& Produção, v. 16, n. 3, p. 489-501, 2009. http:// dx.doi.org/10.1590/S0104-530X2009000300014.

VIEIRA, S. M. J.; RAGA, A.; BENEDETTI, B. C.; OLIVEIRA, R. A.; DI MARCO, P. G.; SCARPONI, A. P. T. Effect of ultraviolet-C radiation on "Kumagai" guavas infested by Ceratitis capitata (Diptera-Tephritidae) and on physical parameters of postharvest. Scientia Horticulturae, v. 165, p. 295-302, 2014. http://dx. doi. org/10.1016/j.scienta.2013.11.015.
VILA, M. T. R.; LIMA, L. C. O.; VILAS-BOAS, E. V. B.; DOLL HOJO, E. T.; RODRIGUES, L. J.; PAULA, N. R. F. Caracterização química e bioquímica de goiabas armazenadas sob refrigeração e atmosfera modificada. Ciência e Agrotecnologia, v. 31, n. 5, p. 1435-1442, 2007. http://dx.doi.org/10.1590/S1413-70542007000500025.

VILAS BOAS, B. M.; ALVES, A. P.; ALVES, J. A.; RODRIGUES, L. J.; ALVES, T. C.; VILAS BOAS, E. V. B. Physical, chemical and biochemical characterization of pequi fruit harvested at different stages of development. Ciência Rural, v. 43, n. 12, p. 2285-2290, 2013.

XISTO, A. L. R. P.; ABREU, C. M. P.; CORRÊA, A. D.; SANTOS, C. D. Textura de goiabas "Pedro Sato" submetidas à aplicação de cloreto de cálcio. Ciência e Agrotecnologia, v. 28, n. 1, p. 113-118, 2004. http://dx.doi.org/10.1590/S1413-70542004000100015. 